Nara, T., Samejima, H., Fujita, C., Ito, M., Nakayama, K. \& Kinoshita, S. (1961). Agric. biol. Chem., Japan, 25, 532. Neuberger, A. (1961). Biochem. J. 78, 1.

Nicholas, R. E. H. \& Rimington, C. (1949). Scand. J. clin. Lab. Invest. 1, 12.

Stadtman, E. R., Cohen, G. N., Lebras, G. \& de RobichonSzulmajster, H. (1961). J. biol. Chem. 236, 2033.

Stanier, R. Y. (1960). The Harvey Lectures, 54, 219.
Tait, G. H. \& Gibson, K. D. (1961). Biochim. biophys. Acta, $52,614$.

Teas, H. J., Horowitz, N. H. \& Fling, M. (1948). J. biol. Chem. 172, 651.

Vaughan, M. \& Steinberg, D. (1959). Advanc. Protein Chem. $14,115$.

Watanabe, Y. \& Shimura, K. (1955). J. Biochem., Tokyo, 42, 181 .

Biochem. J. (1962) 83, 559

\title{
Physicochemical Studies on Ovalbumin
}

\section{THE SULPHYDRYL AND DISULPHIDE CONTENTS OF OVALBUMIN AND AN IODINE-MODIFIED DERIVATIVE*}

\author{
By D. J. WINZOR $\dagger$ AND J. M. CREETH \\ Department of Physical and Inorganic Chemistry, University of Adelaide, Adelaide, South Australia \\ and the Lister Institute of Preventive Medicine, Chelsea Bridge Road, London, S.W. 1
}

(Received 31 July 1961)

The well-known instability of aqueous solutions of ovalbumin at room temperature often causes difficulty in the interpretation of physicochemical measurements on the substance. We attempted to prepare more stable derivatives by modifying the sulphydryl groups of the cysteine residues, since these groups are probably implicated in the aggregation process (Frensdorff, Watson \& Kauzmann, 1953; Halwer, 1954; cf. McKenzie, Smith \& Wake, 1955). Of those reagents for which specificity for sulphydryl groups has been claimed (cf. reviews by Olcott \& Fraenkel-Conrat, 1947; Herriott, 1947; Putnam, 1953), iodine was selected because the available information indicated that the reaction was irreversible and the product stable. However, there is conflicting evidence concerning the specificity of the reaction. Anson \& Stanley (1941) found conditions under which about 5 atoms of iodine reacted per molecule of ovalbumin, and concluded that the reaction was specific, under rather restricted conditions, for the oxidation of sulphydryl groups to disulphide linkages because the modified material no longer gave a nitroprusside test after denaturation, and earlier studies (Greenstein, 1938; Brand \& Kassel, 1940; Anson, 1941) had all indicated the presence of 5 sulphydryl groups/molecule. However, since the sedimentation coefficients of the native and modified materials were found to be essentially identical (Anson, 1942), it appeared that the reaction was entirely intramolecular. Since at least 1 intermolecular

* Part 2: Nichol, Winzor \& Creeth (1960).

$\dagger$ Present address: C.S.I.R.O. Wheat Research Unit, North Ryde, N.S.W., Australia. disulphide bridge must be formed if 5 sulphydryl groups are converted into disulphide linkages, the reported stoicheiometry is incompatible with specificity. We therefore investigated the stoicheiometry of the reaction, and the sulphydryl and disulphide content of starting material and product. In addition, the product has been analysed for iodine by a radiochemical procedure.

Part of this work has been described by Winzor (1960); a preliminary report was presented at the Symposium on Proteins held at Parkville, Victoria, Australia, on 10-11 September 1959, the proceedings of which have been summarized by Thompson (1959).

While this investigation was in progress, Cunning: ham \& Nuenke $(1959,1960)$ reported studies of the reaction between iodine and ovalbumin, carried out under slightly different conditions, and yielding a product which, as discussed below, probably differs from the one we obtained.

\section{EXPERIMENTAL}

Ovalbumin. Four samples of crystalline ovalbumin were used. The first two, denoted AC S2 and AC S3 (Creeth, Nichol \& Winzor, 1958), were prepared by the method of La Rosa (1927), and consisted of a paste of protein crystals and ammonium sulphate. The third, denoted ACK, was prepared by Dr R. A. Kekwick according to the procedure of Kekwick \& Cannan (1936), and consisted of a dry powder containing much sodium sulphate. The fourth, denoted AC Ar, was a commercial crystallized material (Armour and Co. Ltd., Eastbourne, Sussex, Lot no. DM 1490). The last two samples contained a small proportion of material insoluble at $\mathrm{pH} \mathrm{7,} \mathrm{but} \mathrm{the}$ 
solutions obtained from all samples showed no differences in sedimentation or electrophoretic behaviour.

Methylmercuric iodide. This reagent was prepared by the method of Maynard (1932), and recrystallized from ethanol; it had m.p. $144^{\circ}$.

Determination of protein concentrations. This was done refractometrically, either with a double-prismatic differential refractometer (Svensson \& Odengrim, 1952) or by forming a boundary between the protein solution and the buffer solution with which it was in dialysis equilibrium. Optical equipment yielding Rayleigh interference patterns was used in both cases, and the results were recorded photographically. The number of fringes was counted (to the nearest $0 \cdot 1$ ) with a tool-maker's microscope; concentrations were then determined from the value of $1.845 \times 10^{-3} \mathrm{dl} . \mathrm{g}^{-1}$ for the specific refraction increment of ovalbumin at $1^{\circ}$, this being based on the results of Halwer, Nutting \& Brice (1951) and Charlwood (1957), together with those of Perlmann \& Longsworth (1948) for temperature- and concentration-dependence. It was assumed that this value also applies to the iodine-modified product. Molar concentrations were calculated on the basis of a mol.wt. of $\mathbf{4 5 0 0 0}$ for both the native material (Halwer et al. 1951; Fevold, 1951) and the derivative, since there is good evidence that the two molecular weights are virtually identical (Creeth \& Winzor, 1962).

Optical rotation. Measurements of $[\alpha]_{\mathrm{D}}$ were made at room temperature $\left(20-21^{\circ}\right)$ with a 2 dl. tube (Model ' $A$ ' polarimeter, Bellingham and Stanley, 71 Hornsey Rise, London, N. 19). The protein solutions contained $0 \cdot 1 \mathrm{M}-\mathrm{KCl}$ (Schellman, 1958).

Determination of sulphydryl and disulphide contents. Amperometric titration with a dropping-mercury electrode was used, with either mercuric chloride or methylmercuric iodide as reagent. For mercuric chloride the conditions were essentially as described by Stricks, Kolthoff \& Tanaka (1954), except that preliminary hydrolysis was omitted; instead 8M-urea was added to the solution being titrated (Kolthoff, Anastasi, Stricks, Tan \& Deshmukh, 1957; Kolthoff, Anastasi \& Tan, 1958; Leach, 1959). These titrations were performed in an atmosphere of nitrogen with a manual polarograph (Electrochemical Laboratories, Worsley, Lancs.); the equivalence point was obtained from the inflexion point in the graph of current against volume of reagent, with an applied potential of $-0.35 \mathrm{v}$ against a saturated calomel electrode.

Titrations with methylmercuric iodide were performed by the method outlined by Leach (1960), the concentration of reagent being $2 \mathrm{~mm}$ in aq. $25 \%(\mathrm{v} / \mathrm{v})$ dimethylformamide. The medium was phosphate buffer, $\mathrm{pH} 7, I 0 \cdot 20$, and a potential of $-0.70 \mathrm{v}$ against a saturated calomel electrode was applied. For these titrations a Cambridge 'Pen Recording Polarograph' was used with external galvanometer. This arrangement proved to be more sensitive than the recorder.

Titration of ovalbumin with iodine. This was followed potentiometrically with a bright platinum electrode and a saturated calomel electrode (connected via an agarpotassium chloride bridge). The titration was performed in an ice bath, mN-iodine in $\mathrm{M}-\mathrm{KI}$ being run, with manual or magnetic stirring, into $20 \mathrm{ml}$. of ovalbumin solution which also contained $\mathrm{KI}(\mathrm{M}), \mathrm{Na}_{2} \mathrm{HPO}_{4}(0 \cdot 1 \mathrm{M})$ and $\mathrm{NaH}_{2} \mathrm{PO}_{4}$ $(0 \cdot 1 \mathrm{M})$ (pH 6.8).

The reaction under these conditions is not fast, and accordingly several series of titration experiments were carried out. In the first, after each small addition of iodine, the variation of the e.m.f., $E$, with time was followed. An approximately constant value of $E$ was reached only after about $20 \mathrm{~min}$. As the point corresponding to 5 equiv. of iodine/mole of ovalbumin was approached, the drift with time decreased substantially, and above this point $E$ did not change over a period of $30 \mathrm{~min}$. In the second series, therefore, a volume of iodine corresponding to about 4 equiv./mole was added comparatively rapidly, no measurement of $E$ being made. The equivalence point was then determined as before. Fig. $1(a)$ shows a typical curve obtained under the latter conditions, and Fig. $1(b)$ the derivative curve obtained by differentiation; this procedure was generally used to obtain the end points. Both these series of titrations, in which the individual experiments were completed in 1-2 hr., gave the same value for the equivalence point, and are reported together. The shapes of the curves show that the end point is unequivocally established under these conditions, there being
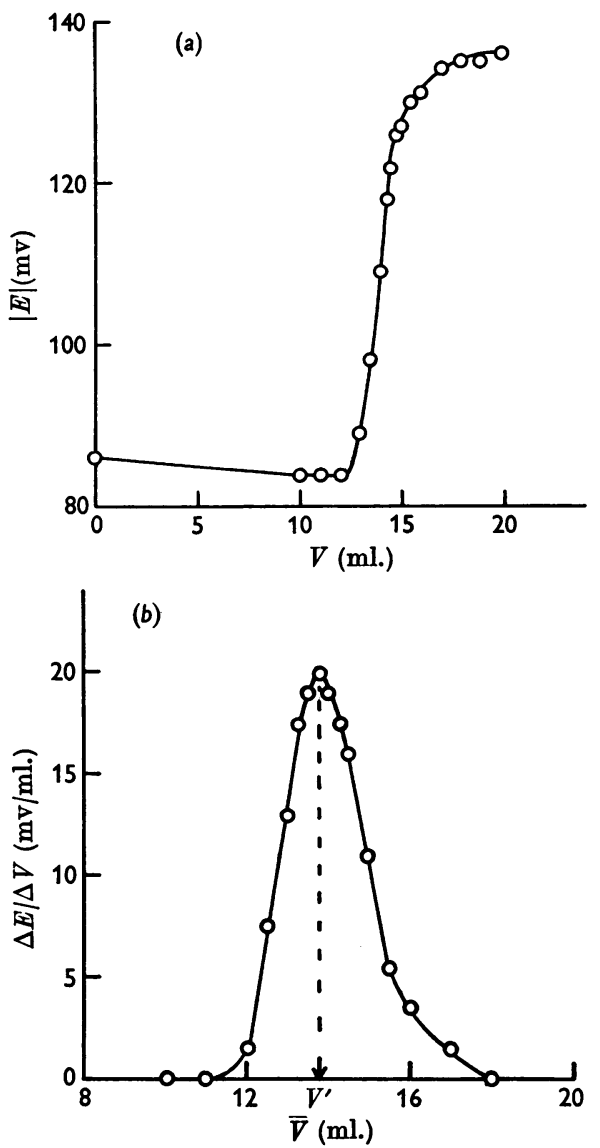

Fig. $1(a)$. Typical potentiometric titration curve for the iodine-ovalbumin reaction: $V$ is the volume of $\mathrm{mN}$ iodine. (b) The derivative curve: $\bar{V}$ is the mean of the two values of $V$ from which $\Delta E / \Delta V$ is obtained. $V^{\prime}$ marks the end point. 
no indication of a second inflexion point. In a third series of titrations, greater precautions were taken to ensure that equilibrium had been attained after each addition of iodine: the experiments were thus prolonged over about 7-9 hr. The results of these gave a slightly higher value for the equivalence ratio, and are reported separately.

In the region of protein excess, the curve of $E$ against volume $(V)$ of added iodine is qualitatively typical of a redox process and thus suggests reversible behaviour of the electrode; however, platinum electrodes do not yield thermodynamically significant values of $E$ when simple thiols are titrated (e.g. Freedman \& Corwin, 1949). Above the equivalence point, $E$ is determined by the iodine: iodide ratio, as would be expected. Thus no greater significance can be attached to the curve than that it is a convenient empirical indication of one end point (out of perhaps several that may be observable) in the reaction between iodine and ovalbumin.

In some cases, after the titration had been completed, the solutions (which contained excess of iodine) were allowed to stand for varying periods and then backtitrated with mN-Nan $\mathrm{S}_{2} \mathrm{O}_{3}$, also in $0.1 \mathrm{M}$-sodium phosphates. The $E$ values obtained were approximately those expected for iodine-thiosulphate titrations, and no drift with time was observed.

These experiments indicated that, as expected, further reaction with iodine took place under certain circumstances, depending on the amount of excess of iodine and the time of standing. After periods of about $10 \mathrm{~min}$., the whole of the excess of iodine was titratable with thiosulphate, hereas 1-2 equiv. of iodine had reacted after 1-4 days. To define more closely the conditions under which well characterized derivatives could be produced, two additional experiments were carried out in which the progress of the reaction was followed solely by backtitration of samples taken at intervals. These are reported as Expts. $A$ and $C$ in Table 2.

All series of forward- and back-titration experiments were controlled with blanks in which the protein solution was replaced by the buffer solution against which it had been finally dialysed; small corrections were applied where necessary.

Preparation of iodine-modified ovalbumin. The same procedure, on a larger scale, was used to prepare the modified protein, the titration being followed only in the region of $5: 1$ equivalence. The mixture thus obtained, which contained 1-1.2 equiv. of iodine in excess, was then immediately dialysed against phosphate buffer, $\mathrm{pH} 7, I$ 0.04, with constant mild agitation and frequent changes of the outer solution in the early stages.

Detection and estimation of iodine in the product. Carrierfree $\mathrm{Na}^{131} \mathrm{I}$ in dilute $\mathrm{NaOH}$ at $\mathrm{pH}$ 8-10 was obtained from The Radiochemical Centre, Amersham, Bucks.

The derivative was prepared as described for the ordinary iodine-modified product, except that the iodineKI solution used as reactant was labelled with 181I. To minimize handling this highly active solution, an amount of it calculated to contain about 6 equiv. of iodine was added directly to the protein solution. Since the exchange between iodine and $\mathrm{I}^{-}$ion is expected to be many times faster than the reaction between the protein and iodine, this procedure resulted essentially in the reaction of the protein with an iodine solution of known activity/g.atom of total iodine (specific activity). The modified protein
Table 1. Stoicheiometry of reaction between ovalbumin and iodine, determined by direot titration

The experimental conditions were: temperature $0^{\circ}$, pH 6.8, 1.0 M-potassium iodide, end point detected potentiometrically. The samples are described in the Experimental section. The value of 45000 has been used for the mol.wt. A, Titrations completed within $2 \mathrm{hr}$.; B, titrations prolonged over 7-8 hr.

\begin{tabular}{|c|c|c|c|c|}
\hline & $\begin{array}{c}\text { Sample } \\
\text { no. }\end{array}$ & $\begin{array}{l}\text { Protein } \\
(\mu \text { moles })\end{array}$ & $\begin{array}{l}\text { Iodine at } \\
\text { end point } \\
\text { ( } \mu \mathrm{g} \text { atoms) }\end{array}$ & $\begin{array}{c}\text { Iodine } \\
\text { reacting } \\
\text { (atoms/ } \\
\text { molecule } \\
\text { of protein) }\end{array}$ \\
\hline $\mathbf{A}$ & $\begin{array}{l}\text { AC S2 } \\
\text { AC S3 } \\
\text { AC S3 } \\
\text { AC S3 } \\
\text { AC S3 } \\
\text { AC Ar } \\
\text { AC K }\end{array}$ & $\begin{array}{l}6 \cdot 53 \\
3 \cdot 76 \\
3 \cdot 76 \\
3 \cdot 76 \\
7 \cdot 51 \\
2 \cdot 26 \\
1 \cdot 26\end{array}$ & $\begin{array}{r}32 \cdot 3 \\
19 \cdot 0 \\
18 \cdot 6 \\
18 \cdot 6 \\
37 \cdot 8 \\
11 \cdot 1 \\
6 \cdot 4\end{array}$ & $\begin{array}{l}4 \cdot 9_{5} \\
5 \cdot 0_{5} \\
4 \cdot 9_{5} \\
4 \cdot 9_{5} \\
5 \cdot 0_{3} \\
4 \cdot 9_{0} \\
5 \cdot 0\end{array}$ \\
\hline B & $\begin{array}{l}\text { AC Ar } \\
\operatorname{AC~K} \\
A C K\end{array}$ & $\begin{array}{l}2 \cdot 75 \\
2 \cdot 10 \\
1 \cdot 77\end{array}$ & $\begin{array}{r}14 \cdot 6 \\
11 \cdot 0 \\
9 \cdot 5\end{array}$ & $\begin{array}{l}5 \cdot 3_{1} \\
5 \cdot 2_{2} \\
5 \cdot 3_{8}\end{array}$ \\
\hline
\end{tabular}

was then dialysed as before but with phosphate buffer, pH 7, I 0.20. The activity of the outer solution in equilibrium (i.e. after $24 \mathrm{hr}$. in contact) with the protein solution was measured to determine the extent of removal of free iodine and $\mathrm{I}^{-}$ion. The activity of the protein solution was first measured after 8 days, when the activity of the outer solution was 200 counts/100 sec. above the normal background count of 150 counts/100 sec.; the outer solution count was used as 'background' to obtain the protein solution activity. This was then compared with the activity of a solution of known total iodine concentration, prepared at the beginning of the experiment to avoid any correction of activities for time effects. Activities were determined with a scintillation counter and automatic scalar unit (EKCO Electronics Ltd., Southend-on-Sea, Essex). Since iodide may well be bound rather strongly to the protein, and hence be removed by dialysis only slowly, a protein solution was dialysed against the phosphate until the outer solution count was reduced to the normal background level; a further 3 days were required. A similar protein solution was also dialysed against a veronalchloride buffer, $\mathrm{pH} \mathrm{8.5,I} 0 \cdot 10$, for the final 3 days to determine whether the smaller $\mathrm{Cl}^{-}$ion was more effective in removing activity from the protein.

\section{RESULTS}

Titration of ovalbumin with iodine. In this work the experimental conditions (especially the use of M-potassium iodide) were identical with those of Anson (reported by Anson \& Stanley, 1941), except that the end point was determined potentiometrically whereas Anson used a positive starch or negative nitroprusside test. Table 1 gives absolute quantities of ovalbumin and iodine at the equivalence point of the titrations: 5 atoms of iodine react per molecule of ovalbumin, if the titration is completed within $2 \mathrm{hr}$. However, a slightly greater 
amount of iodine may react over 7-8 hr. Table 2 summarizes the effect of standing on reaction mixtures of ovalbumin and iodine: the 5:1 derivative reacts slowly with excess of iodine even when only 1.2 equiv. is present. At periods of up to $1 \mathrm{hr}$., however, the extent of this reaction is negligible. Hence the preparation procedure used in this work yields essentially only the $5: 1$ product, since the excess of iodine was removed by dialysis commencing immediately after preparation; the $50 \%$ escape time for iodine from dialysis sacs under the conditions used is less than $30 \mathrm{~min}$.

The further reactions are much more rapid when 3 equiv. of iodine is present in excess of the $5: 1$ ratio; there are also some indications that a $6: 1$ product has an independent existence. At least 7 atoms of iodine will react per molecule of ovalbumin if the reaction mixture is left for 2-4 days.

Sulphydryl and disulphide content of ovalbumin and the iodine-modified product. The first series of estimations of the sulphydryl and disulphide content of the two materials were carried out with mercuric chloride as the reagent. Under the conditions used, mercuric chloride apparently acts as a monofunctional reagent with naturally occurring sulphydryl groups (Kolthoff et al. 1957; Leach, 1960; cf. however, Allison \& Cecil, 1958), but when used to react with those sulphydryl groups arising from the scission of disulphide bonds by sulphite

Table 2. Effect of time of standing and iodine concentration on stoicheiometry of iodine-ovalbumin reaction

Conditions are as given in Table 1 . Values in the second column refer to time elapsed after completion of the addition of iodine. Excess of iodine was determined potentiometrically with sodium thiosulphate. Reaction mixtures: $A, 2: 13 \mu$ moles of protein and $13 \cdot 1, \mu$ g.atoms of iodine (6.21:1); B, $2.75 \mu$ moles of protein and $17 \cdot 8_{0} \mu$ g.atoms of iodine $(6.45: 1)$; C, 3.24 $\mu$ moles of protein and $25.9_{5} \mu \mathrm{g}$.atoms of iodine $(8.00: 1) ; D, 1.77 \mu$ moles of protein and 13.5 $\mu$ g.atoms of iodine $(7.65: 1) ; \mathrm{E}, 2.26 \mu$ moles of protein and $17 \cdot 5_{2} \mu$ g.atoms of iodine $(7 \cdot 75: 1)$.

$\begin{array}{ccc}\begin{array}{c}\text { Reaction } \\ \text { mixture }\end{array} & \begin{array}{c}\text { Time of } \\ \text { standing } \\ \text { (hr.) }\end{array} & \begin{array}{c}\text { Iodine reacting } \\ \text { (atoms/molecule } \\ \text { of ovalbumin) }\end{array} \\ \text { A } & 1 & 5 \cdot 0_{6} \\ & 2 & 5 \cdot 2_{1} \\ \text { B } & 3 \frac{1}{2} & 5 \cdot 3 \\ \text { C } & 24 & 6 \cdot 1 \\ & 48 & 5 \cdot 9 \\ & 1 & 5 \cdot 5_{5} \\ & 2 & 5 \cdot 6_{1} \\ \text { D } & 3 & 5 \cdot 7_{4} \\ \text { E } & 5 \frac{1}{2} & 5 \cdot 9_{3} \\ & 24 & 6 \cdot 4_{1} \\ & 48 & 6 \cdot 9_{2} \\ & 96 & 7 \cdot 1\end{array}$

action it acts as a difunctional reagent (Kolthoff et al. 1958; Leach, 1959, 1960). Since only 1 sulphydryl group is formed when sulphite reacts with a disulphide group (Clarke, 1932; Lugg, 1932), the postulated difference in stoicheiometry can be accounted for only by invoking different mechanisms for the reaction of mercuric chloride with naturally occurring sulphydryl groups on the one hand, and with those produced from disulphide bonds on the other. At first sight this is arbitrary and unsatisfactory, but the explanation has been verified experimentally with proteins such as bovine serum albumin and insulin for which reliable independent data on the sulphydryl and disulphide content are available (Stricks et al. 1954, Kolthoff et al. 1957, 1958; Leach, 1959, 1960; Kolthoff, Anastasi \& Tan, 1959; Hughes, 1949; Swan, 1959).

In these circumstances, because some uncertainty in the stoicheiometry must nevertheless persist when any 'unknown' substance is investigated (cf. Allison \& Cecil, 1958), we report our experimental results in terms of the operationally defined quantity, $Q$, the number of formula weights of reagent (mercuric chloride or methylmercuric iodide) reacting per mole of protein. When the reagent is mercuric chloride, the sulphydryl content as measured in the absence of sulphite is equal to the value of $Q$ obtained, and the disulphide content (requiring an additional estimation in the presence of sulphite) is given by: disulphide content (mercuric chloride as titrant) $=2\left[Q_{\text {(eulphte added })}-\right.$ $Q_{\text {(no salpaste) }}$. Cystine of $99.7 \%$ purity (California Foundation for Biochemical Research) gave 0.961.00 (mean 0.98) disulphide group/molecule.

To confirm the validity of sulphydryl and disulphide estimations thus obtained, a second series of analyses were performed, with the monofunctional reagent methylmercuric iodide, by the method of Leach (1960). Although the ratio of the number of formula weights of reagent/mole of protein is unambiguous in this case, the results are also reported in terms of $Q$ for easy comparison with the series in which mercuric chloride was used. The same sample of cystine gave 0.98-1.00 disulphide group/molecule.

As is shown in Table 3, both reagents agree in indicating that there are 4 sulphydryl and 2 disulphide groups/molecule in the native protein, and 2 sulphydryl and 2 disulphide groups/molecule in the modified protein.

Iodine content of modified protein. The results of the radiochemical assays indicate (Table 4) that iodine is incorporated into the modified product. In view of the experimental limitations, the value of $1 \cdot 0$, iodine atoms/molecule (obtained after exhaustive dialysis against phosphate) is a reasonable approximation to unity as is the lower value 


\section{Table 3. Estimation of sulphydryl and disulphide content of native and iodine-modified ovalbumin}

The number of separate determinations of the two values of $Q$ is indicated in parentheses after the 'Material'. All values fell within $\pm 0 \cdot 1$ of the stated figure.

\begin{tabular}{llcccc}
\multicolumn{1}{c}{ Material } & Reagent & $Q_{\text {(no sulphito) }}$ & $Q_{\text {(oulphtto addod) }}$ & $\begin{array}{r}\text { content } \\
\text { (groups/molecule) }\end{array}$ & $\begin{array}{c}\text { content } \\
\text { (groups/molecule) }\end{array}$ \\
Ovalbumin (5) & $\mathrm{HgCl}_{2}$ & $3 \cdot 8$ & $4 \cdot 9$ & 4 & 2 \\
Modified ovalbumin (4) & $\mathrm{HgCl}_{2}$ & $1 \cdot 9$ & $3 \cdot 0$ & 2 & 2 \\
Ovalbumin (3) & $\mathrm{CH}_{3} \mathrm{HgI}_{3}$ & $4 \cdot 0$ & $6 \cdot 0$ & 4 & 2 \\
Modified ovalbumin (3) & $\mathrm{CH}_{3} \mathrm{HgI}$ & $1 \cdot 9$ & $3 \cdot 9$ & 2 & 2
\end{tabular}

\section{Table 4. Incorporation of labelled iodine into iodine-modified ovalbumin}

Activities are given in counts/100 sec., corrected for background counts (the 'outer solution' counts for the protein solutions). The volume inside the dialysis sac was approx. $19 \mathrm{ml}$. in each case; before counting the protein solutions, the whole contents were removed and made up to $25.0 \mathrm{ml}$. Dialysis, with frequent changes of outer solution, was continued for the periods indicated: (P) refers to phosphate, pH $7 \cdot 0, I=0 \cdot 20$, and (V) to veronal-chloride, pH 8.5, $I=0 \cdot 10$. The column headed 'Specific activity' (see Experimental section) is derived from the count, and iodine content, of the standard solution, but the values apply to both sets of activities.

\begin{tabular}{|c|c|c|c|c|c|c|}
\hline $\begin{array}{c}\text { Protein } \\
\text { used } \\
\left(\text { moles } \times 10^{6}\right)\end{array}$ & $\begin{array}{c}\text { Time of } \\
\text { dialysis } \\
\text { (days) }\end{array}$ & $\begin{array}{c}\text { Activity of } \\
\text { protein soln. }\end{array}$ & $\begin{array}{l}\text { Activity of } \\
\text { standard } \\
\text { soln. }\end{array}$ & $\begin{array}{c}10^{9} \times \text { specific } \\
\text { activity }\end{array}$ & $\begin{array}{c}10^{9} \times \text { activity } / \\
\text { mole of } \\
\text { protein }\end{array}$ & $\begin{array}{c}\text { content } \\
\text { (atoms/ } \\
\text { molecule } \\
\text { of protein) }\end{array}$ \\
\hline $\begin{array}{l}6 \cdot 22 \\
6 \cdot 22 \\
2 \cdot 49 \\
2 \cdot 49\end{array}$ & $\begin{array}{r}8(\mathrm{P}) \\
8(\mathrm{P}) \\
11(\mathrm{P}) \\
8(\mathrm{P}) \\
+3(\mathrm{~V})\end{array}$ & $\left.\begin{array}{r}16000 \\
16900 \\
3820 \\
3310\end{array}\right\}$ & 17000 & $3 \cdot 58$ & $\begin{array}{r}\left\{\begin{array}{l}6 \cdot 44 \\
6 \cdot 79\end{array}\right. \\
\left\{\begin{array}{l}3 \cdot 83 \\
3 \cdot 33\end{array}\right.\end{array}$ & $\begin{array}{l}1 \cdot 2_{4} \\
1 \cdot 3_{1} \\
1 \cdot 0_{7} \\
0.9_{3}\end{array}$ \\
\hline
\end{tabular}

of $0 \cdot 9_{3}$ (obtained after exhaustive dialysis against the smaller $\mathrm{Cl}^{-}$ion).

Optical rotation. Values of $[\alpha]_{\mathrm{D}}^{20}$ of $-30 \cdot 3$ and $-31.7^{\circ}$ were found, respectively, for native ovalbumin and the modified product. Since these figures are based on actual rotations of only about $0 \cdot 4^{\circ}$, the uncertainty in $[\alpha]_{D}^{20}$ is about $\pm 1.5^{\circ}$, but it is certain that no substantial change is brought about by the modification process. Under the same conditions, Schellman (1958) found $[\alpha]_{\mathrm{D}}^{20}$ for ovalbumin to be $-29 \cdot 7^{\circ}$.

Solubility. At $1^{\circ}$ and $I 0 \cdot 10$, ovalbumin has a very high solubility over the $\mathrm{pH}$ range $4-8.5$, whereas the solubility of the derivative is $>3 \%$ $(\mathrm{w} / \mathrm{v})$ at $\mathrm{pH} 7 \cdot 0-8 \cdot 5,<3 \%$ at $\mathrm{pH} 5 \cdot 5-7 \cdot 0$, and very low $(\sim 0.03 \%)$ at the isoelectric point, $\mathrm{pH} \mathrm{4.6}$. At $25^{\circ}$ and $I 0 \cdot 10$, the solubility of the modified material is higher (though still much less than that of the original), being, for example, $0 \cdot 4 \%$ at $\mathrm{pH} 4 \cdot 6$.

Stability. At $1^{\circ}$ and $I 0 \cdot 10$, solutions of native ovalbumin become cloudy and slowly precipitate; solutions of the derivative, however, remain clear under these conditions ( $\mathrm{pH} \mathrm{5.5-8.5)}$ for some months, and no variation in the characteristics of the electrophoretic pattern is observable with the passage of time [cf. the behaviour of ovalbumin, (Creeth et al. 1958)]. At $25^{\circ}$ and $I$ 0.10, both materials are precipitated quite rapidly, the solids being apparently denatured.
Even though the solubility of the modified material at $\mathrm{pH} 4.6, I 0.10$ and $1^{\circ}$ is small, a genuine equilibrium appears to be established between the liquid and solid phases; the latter is therefore presumed to be undenatured. This conclusion is supported by the following electrophoretic evidence. A solution was adjusted from $\mathrm{pH} 8.5$ to 4.6 and the precipitate removed by centrifuging; the precipitate redissolved readily and completely at pH 8.5. The electrophoretic characteristics of the resulting solution were compared (at $\mathrm{pH} 8.5$ and $I 0 \cdot 10$ ) with those of the original solution and (so far as possible) with those of the material which had stayed in solution at $\mathrm{pH} 4.6$, after redialysis to $\mathrm{pH}$ 8.5. No differences could be observed in the shapes of the peaks, and the descending mobilities were all $-6.5( \pm 0.05) \times 10^{-5} \mathrm{~cm}^{2} \mathrm{sec}^{-1} \mathrm{v}^{-1}$. It is assumed that any major change in the secondary structure would be reflected in the mobility value.

Colour. The 5:1 product has no noticeable colour at concentrations up to $1 \%$. The 6:1 product, obtained by allowing the former derivative to stand with 1.0 equiv. of iodine for 1 or more days, is also colourless at concentrations up to $0.5 \%$. In all back-titration experiments, which indicated the reaction of 5-7 equiv. of iodine, depending on the conditions, the reaction mixture was colourless at the end point. 


\section{DISCUSSION}

Although the finding of 4 sulphydryl groups/ molecule in denatured ovalbumin is in agreement with most recent determinations [reviewed by Cecil \& McPhee (1959)], the results obtained under different conditions show unexpectedly poor agreement; possible causes of this have been discussed by Leach (1960) who himself obtained values between 3 and 5 , depending on the time allowed for titration. The result for the disulphide content (2 groups/molecule) is not in agreement with that of Leach (1960), who quotes a maximum figure of 5.3 for the total (sulphydryl plus disulphide) groups and was unable to distinguish between disulphide groups and slowly reacting sulphydryl groups. Since the reactivity of the sulphydryl and disulphide groups in ovalbumin is so sensitive to minor changes in experimental conditions, the discrepancy is probably not indicative of a genuine difference between samples, and we attach more importance to the fact that no change in apparent disulphide content occurs on reaction with iodine than to the numerical values themselves. It must be pointed out that our figures give a total of 8 (cystine + cysteine) sulphur atoms/ molecule. Tristram (1953) reports one cystine and five cysteine residues from amino acid analysis, giving a total of 7 (cystine + cysteine) sulphur atoms, with which the more recent data of Kuratomi, Ohno \& Akabori (1957), who found 7.3, and of Akabori \& Fujiwara (1958), who found 6.8, are in substantial agreement. While this discrepancy remains to be resolved, the possibility of low results for cyst(e)ine sulphur in amino acid analyses is recognized (e.g. Cecil \& McPhee, 1959).

The agreement between the disulphide estimations based on the use of mercuric chloride and of methylmercuric iodide validates the stoicheiometry of reactions involving mercuric chloride proposed by Kolthoff et al. $(1957,1958)$ and by Leach (1960). The mechanism of the reactions is still obscure.

The observed stoicheiometry of the initial reaction between iodine and ovalbumin ( 5 atoms/ molecule) when carried out at $0^{\circ}, \mathrm{pH} 6.8$ and in the presence of M-potassium iodide (Anson \& Stanley, 1941), confirms that proposed by Anson (1945), but is somewhat more conclusive than his value of 4.4-4.5. This probably indicates that the electrochemical method of end-point detection is more satisfactory than the use of starch or nitroprusside (cf. Larson \& Jenness, 1950). The results of the experiments in which the protein stood in contact with excess of iodine indicate, in general agreement with previous work, that more than one product may result from the reaction; of these, the 5:1 product is the first-produced and simplest under the conditions used in this work. The factors which influence the stoicheiometry include $\mathrm{pH}$, temperature, concentration of potassium iodide and state of the protein, but some conflicting evidence exists. The relevant data are collected in Table 5 where, because of the method of representation, some values may differ trivially from those originally reported. The extensive experiments of Cunningham \& Nuenke $(1959,1960)$ were performed under conditions which most closely resembled ours. Their finding of $6: 1$ equivalence, at a temperature of $5^{\circ}$ and in the presence of $0.2 \mathrm{M}$-potassium iodide, appears directly comparable with the finding of 6 (or more): 1 equivalence over long reaction times reported here. They reported that their product was yellow, and indeed that absorption at the same characteristic value as for $\mathrm{I}_{3}^{-}$ion increased during the titration; however, the colour of the $6: 1$ product faded on standing. Our observations confirm that a colourless 6:1 derivative may be produced by rather prolonged exposure to dilute iodine. The derivative which we have examined

Table 5. Effect of varying conditions on reported stoicheiometry of iodine-ovalbumin reaction

The columns headed ' $\mathrm{pH}$ ' and 'Concn. of KI' refer to the protein solution before addition of titrant.

\begin{tabular}{|c|c|c|c|c|c|}
\hline Investigator & pH & $\begin{array}{l}\text { Concn. } \\
\text { of } \mathbf{K I} \\
\text { (M) }\end{array}$ & Temp. & $\begin{array}{l}\text { Iodine reacting } \\
\text { (atoms/molecule } \\
\text { of native } \\
\text { protein) }\end{array}$ & $\begin{array}{c}\text { Additional } \\
\text { iodine reacting } \\
\text { on denaturation } \\
\text { (atoms/molecule } \\
\text { of protein) }\end{array}$ \\
\hline Anson (1940) & $6 \cdot 8$ & $0 \cdot 0$ & $0^{\circ}$ & $5 \cdot 9$ & $0 \cdot 0$ \\
\hline Anson (1941) & $3 \cdot 2$ & 0.0 & 37 & $6 \cdot 8$ & 0.0 \\
\hline $\begin{array}{l}\text { Anson (reported by Anson \& Stanley, } \\
\text { 1941) }\end{array}$ & $6 \cdot \overline{8}$ & $1 \cdot 0$ & 0 & $4 \cdot 4-4 \cdot 5$ & $0 \cdot 0$ \\
\hline Hess \& Sullivan (1943) & $\mathbf{3 \cdot 5}$ & - & 20 & $5 \cdot 2$ & 0.0 \\
\hline Larson \& Jenness (1950) & $1 \cdot 5-2 \cdot 0$ & 0.01 & - & $5 \cdot \overline{6}$ & - \\
\hline MacDonnell, Silva \& Feeney (1951) & $\mathbf{3} \cdot \mathbf{2}$ & 0.0 & - & $4 \cdot 1$ & $0.9_{5}$ \\
\hline Cunningham \& Nuenke (1959) & $6 \cdot 5$ & 0.2 & $\mathbf{5}$ & $\begin{array}{c}6 \cdot 1 \\
(5 \cdot 0 \text { (initial) }\end{array}$ & - \\
\hline This work & $6 \cdot 8$ & $1 \cdot 0$ & 0 & $\left\{\begin{array}{c}6-7 \text { (on long } \\
\text { standing) }\end{array}\right.$ & 一 \\
\hline
\end{tabular}


was characterized after removal of any iodine in excess of 5 equiv., and therefore differs from that obtained by Cunningham \& Nuenke. From the evidence reported here and from physicochemical results presented in the next paper (Creeth \& Winzor, 1962), it seems likely that it is comparable in homogeneity with native ovalbumin and is identical with the product obtained by Anson.

The finding that the iodine-modified protein still contains 2 sulphydryl groups but has not more than 2 disulphide groups is at first sight surprising; the absence of additional disulphide groups must mean that the 2 sulphydryl groups lost in the reaction have been oxidized beyond the disulphide stage [cf. the findings of Hughes \& Straessle (1950) on human serum albumin], and that the 2 sulphydryl groups which are not affected by iodine are presumably sterically protected. Thus the reported specificity (Anson, 1945) of iodine for converting sulphydryl into disulphide groups is not well-founded. This conclusion is in agreement with that of Fraenkel-Conrat (1955) and of Cunningham \& Nuenke (1959), and supports the general concept of non-specificity of iodine in protein reactions (Hughes \& Straessle, 1950). There is, moreover, indirect evidence that sulphydryl groups remain in the modified protein: Halwer (1954) found that intermolecular crosslinking still occurs in denatured iodine-treated ovalbumin, which can be interpreted as indicating the presence of both sulphydryl and disulphide groups (cf. however, McKenzie et al. 1955). Myrbäck (1958) found that the product still reacts to a minor extent with $\mathrm{Ag}^{+}$ion, though the nitroprusside test is not given (Anson, 1940). It is well established that 2 sulphydryl groups of ovalbumin are more reactive than the others (Horowitz \& Klotz, 1956; Klotz, Ayers, Ho, Horowitz \& Heiney, 1958).

The finding that 1 iodine atom is incorporated into the molecule of modified ovalbumin confirms, qualitatively, a report by Fraenkel-Conrat (1955) that iodine is present, but is significantly higher than his value of about $0 \cdot 5$. The product obtained by Cunningham \& Nuenke (1959) after reaction with 6 iodine atoms/molecule was found, by an unspecified analytical procedure, to contain 1.4-1.7 iodine atoms/molecule. It also had $[\alpha]_{\mathrm{D}}^{20}$ identical with that of the original. Since it is recognized (e.g. Schellman \& Schellman, 1958) that the optical rotation of a protein is largely determined by its secondary structure (Linderstrøm-Lang, 1952), the finding that no change in rotation accompanies the iodine treatment indicates that the secondary structure of native ovalbumin is largely conserved in the derivative. The decrease in solubility indicates, however, that major changes in the tertiary structure have been brought about.

\section{SUMMARY}

1. The reaction between ovalbumin and iodine at $0^{\circ}$ in the presence of $\mathrm{M}$-potassium iodide has been studied: the end point, obtained potentiometrically, indicated a stoicheiometry of 5 iodine atoms/ molecule of ovalbumin. On standing with excess of iodine, a total of 6-7 iodine atoms react.

2. An amperometric-titration procedure, with either mercuric chloride or methylmercuric iodide, has been used to estimate the sulphydryl and disulphide content of both the native material and the product obtained after reaction with 5 equiv. of iodine. The results indicate that ovalbumin possesses 4 sulphydryl and 2 disulphide groups/ molecule, and the modified product has 2 sulphydryl and 2 disulphide groups/molecule.

3. Iodine analysis of the iodine-treated material with a radiochemical procedure shows the presence of 1 iodine atom/molecule.

4. No change in optical rotation accompanies the iodine treatment, but the solubility of the product is greatly reduced compared with the native material. Solutions of the product are more stable at low temperatures than solutions of the native material.

5. The effect of environmental conditions on the stoicheiometry indicates that several products can potentially be formed. Under the conditions used here, the 5:1 product is formed first. No conditions are yet known under which iodine is a specific reagent for sulphydryl groups alone.

We thank Dr S. J. Leach, of the Commonwealth Scientific and Industrial Research Organization Division of Protein Chemistry, Parkville, Victoria, Australia, for giving us details of the amperometric titration technique with methylmercuric iodide before publication, Dr B. O. West, of the University of Adelaide, for advice and assistance with the experiments involving radioactive iodine, and Dr R. A. Kekwick, of the Lister Institute of Preventive Medicine, for the gift of one of the samples of ovalbumin and for criticism of the manuscript. We are indebted to the Commonwealth Scientific and Industrial Research Organization for a studentship held by D.J.W. throughout this study.

\section{REFERENCES}

Akabori, S. \& Fujiwara, T. (1958). Bull. Soc. Chim. biol. 40, 1983.

Allison, A. C. \& Cecil, R. (1958). Biochem. J. 69, 27.

Anson, M. L. (1940). J. gen. Physiol. 23, 321.

Anson, M. L. (1941). J. gen. Physiol. 24, 399.

Anson, M. L. (1942). J. gen. Physiol. 25, 355.

Anson, M. L. (1945). Advanc. Protein Chem. 2, 361.

Anson, M. L. \& Stanley, W. M. (1941). J. gen. Physiol. 24, 679.

Brand, E. \& Kassell, B. (1940). J. biol. Chem. 133, 437.

Cecil, R. \& McPhee, J. R. (1959). Advanc. Protein Chem. 14, 255.

Charlwood, P. A. (1957). J. Amer. chem. Soc. 79, 776. 
Clarke, H. T. (1932). J. biol. Chem. 97, 235.

Creeth, J. M., Nichol, L. W. \& Winzor, D. J. (1958). J. phys. Chem. 62, 1546.

Creeth, J. M. \& Winzor, D. J. (1962). Biochem. J. 83, 566.

Cunningham, L. W. \& Nuenke, B. J. (1959). J. biol. Chem. 234, 1447.

Cunningham, L. W. \& Nuenke, B. J. (1960). J. biol. Chem. 235, 1711.

Fevold, H. L. (1951). Advanc. Protein Chem. 6, 187.

Fraenkel-Conrat, H. (1955). J. biol. Chem. 217, 373.

Freedman, L. D. \& Corwin, A. H. (1949). J. biol. Chem. $181,601$.

Frensdorff, H. K., Watson, M. T. \& Kauzmann, W. (1953). J. Amer. chem. Soc. 75, 5157.

Greenstein, J. P. (1938). J. biol. Chem. 125, 501.

Halwer, M. (1954). J. Amer. chem. Soc. 76, 183.

Halwer, M., Nutting, G. C. \& Brice, B. A. (1951). J. Amer. chem. Soc. 73, 2786.

Herriott, R. M. (1947). Advanc. Protein Chem. 3, 169.

Hess, W. C. \& Sullivan, M. X. (1943). J. biol. Chem. 151, 635.

Horowitz, M. G. \& Klotz, I. M. (1956). Arch. Biochem. Biophys. 63, 77.

Hughes, W. L., jun. (1949). Cold Spr. Harb. Symp. quant. Biol. 14, 84.

Hughes, W. L., jun. \& Straessle, R. (1950). J. Amer. chem. Soc. 72, 452.

Kekwick, R. A. \& Cannan, R. K. (1936). Biochem. J. 30, 226.

Klotz, I. M., Ayers, J., Ho, J. Y. C., Horowitz, M. G. \& Heiney, R. E. (1958). J. Amer. chem. Soc. 80, 2132.

Kolthoff, I. M., Anastasi, A., Stricks, W., Tan, B. H. \& Deshmukh, G. S. (1957). J. Amer. chem. Soc. 79, 5102.

Kolthoff, I. M., Anastasi, A. \& Tan, B. H. (1958). J. Amer. chem. Soc. 80, 3235.

Kolthoff, I. M., Anastasi, A. \& Tan, B. H. (1959). J. Amer. chem. Soc. 81, 2047.

Kuratomi, K., Ohno, K. \& Akabori, S. (1957). J. Biochem. 44, 183.
La Rosa, W. (1927). Chem. Anal. 16, 3.

Larson, B. L. \& Jenness, R. J. (1950). J. Dairy Sci. 33, 890.

Leach, S. J. (1959). Biochim. biophys. Acta, 33, 264.

Leach, S. J. (1960). Aust. J. Chem. 13, 520.

Linderstrøm-Lang, K. (1952). Lane Medical Lectures, vol. 6, p. 58. Stanford: Stanford University Press.

Lugg, J. W. H. (1932). Biochem. J. 26, 2144.

MacDonnell, L. R., Silva, R. V. \& Feeney, R. E. (1951). Arch. Biochem. Biophys. 32, 288.

McKenzie, H. A., Smith, M. B. \& Wake, R. G. (1955). Nature, Lond., 176, 738.

Maynard, J. L. (1932). J. Amer. chem. Soc. 54, 2108.

Myrbäck, K. (1958). Acta chem. scand. 12, 839.

Nichol, L. W., Winzor, D. J. \& Creeth, J. M. (1960). J.phys. Chem. 64, 1080.

Olcott, H. S. \& Fraenkel-Conrat, H. (1947). Chem. Rev. 41, 151.

Perlmann, G. E. \& Longsworth, L. G. (1948). J. Amer. chem. Soc. 70, 2719.

Putnam, F. W. (1953). In The Proteins, vol. 1 B, p. 893. Ed. by Neurath, H. \& Bailey, K. New York: Academic Press Inc.

Schellman, J. A. (1958). C.R. Lab. Carlsberg, Sér. chim. 30, 429.

Schellman, J. A. \& Schellman, C. (1958). C.R. Lab. Carlsberg, Sér. chim. 30, 463.

Stricks, W., Kolthoff, I. M. \& Tanaka, N. (1954). Analyt. Chem. 26, 299.

Svensson, H. \& Odengrim, K. (1952). Acta chem. scand. 6, 720.

Swan, J. M. (1959). In Symp. on Sulphur in Proteins, p. 3. Ed. by Benesch, R. et al. New York: Academic Press Inc.

Thompson, E. O. P. (1959). Nature, Lond., 184, 1276.

Tristram, G. R. (1953). In The Proteins, vol. $1 \mathrm{~A}$, p. 181. Ed. by Neurath, H. \& Bailey, K. New York: Academic Press Inc.

Winzor, D. J. (1960). Ph.D. Thesis: University of Adelaide.

Biochem. J. (1962) 83, 566

\title{
Physicochemical Studies on Ovalbumin
}

\section{CHARACTERIZATION OF AN IODINE-MODIFIED DERIVATIVE BY ELECTROPHORESIS AND SEDIMENTATION*}

\author{
BY J. M. CREETH AND D. J. WINZOR†
}

The Lister Institute of Preventive Medicine, Chelsea Bridge Road, London, S.W. 1, and the Department of Physical and Inorganic Chemistry, University of Adelaide, Adelaide, South Australia

\section{(Received 31 July 1961)}

Winzor \& Creeth (1962) described the preparation of an iodine-modified derivative of ovalbumin by reaction with 5 equiv. of iodine at $0^{\circ}$, at $\mathrm{pH} 6.8$

* Part 3: Winzor \& Creeth (1962).

$\dagger$ Present address: C.S.I.R.O. Wheat Research Unit, North Ryde, N.S.W., Australia. and in the presence of potassium iodide (M). In some respects the derivative was markedly different from the parent material, whereas in others there was a close similarity between the two substances. Since differences in the transport properties are easiest to interpret directly, a com- 